\title{
Effects of boron (sodium pentaborate), added instead of Tris components, on freezing and post-thaw quality of Angora buck semen*
}

\author{
Mehmet Borga TIRPAN, Necmettin TEKIN
}

Ankara University, Faculty of Veterinary Medicine, Department of Reproduction and Artificial Insemination, Ankara, Turkey.

\begin{abstract}
Summary: In this research, we aimed to evaluate freezing and in vitro results of post-thawed Angora goat semen parameters using boron (sodium pentaborate, $\mathrm{Na}_{2} \mathrm{O} \cdot 5 \mathrm{~B}_{2} \mathrm{O}_{3} \cdot 10 \mathrm{H}_{2} \mathrm{O}$ ) instead of other components and as an additive in Tris extender. Mature Angora bucks, with proven fertility, accustomed to artificial vagina, and with normospermic values have been used in the study. Research was carried out with 9 different extenders: Boron extenders prepared by adding different amounts of Boron instead of glucose into standard Tris extender (GIB, 1-a and 1-b, 1-c, 1-d), the standard Tris extenders prepared by only addition of different amounts of Boron (BAD; 2-a, 2-b, 2-c, 2-d) and standard Tris extender (Control). Post-thaw spermatological examinations have been done with sperm analyzer (CASA) and results were recorded as follows; the highest total and progresive motility scores between 9 different extenders belonged to 1 -c with $63,34 \pm 2,32$ and 1 -d with $\% 38,27 \pm 0,74$, highest VCL, VSL, VAP, LIN, STR and WOB average scores were found in 2 -d extender $(\mathrm{p}<0,001)$. The percentage of lowest dead spermatozoa rate $\% 42,175 \pm 1,59$ was observed with GIB between main groups $(\mathrm{p}<0,01)$. Between extenders, lowest dead spermatozoa rates were recorded as $\% 36,04 \pm 2,58$ and $\%$ $36,17 \pm 3,66$ in $2-b$ and $1-c(p<0,001)$. When abnormal spermatozoa rates were examined, lowest abnormal spermatozoon rate belonged to 2 -c extender with $21,29 \pm 0,97(\mathrm{p}<0,001)$ and abnormal acrosome rates were obtained from $\% 6,57 \pm 1,291$-a extender with $(\mathrm{p}<0,01)$. In conclusion, some positive effects of sodium pentaborate on post-thaw spermatological parameters of Angora buck semen have been demonstrated.
\end{abstract}

Key words: Angora bucks, boron, semen, spermatological parameters.

\section{Ankara tekesi spermasının dondurulmasında Tris sulandırıcı bileşenleri yerine katilan borun (sodyum pentaborat) çözüm sonu sperma kalitesi üzerine etkisi}

Özet: $\mathrm{Bu}$ araştırmada, Ankara tekesi spermasının dondurulması ve çözdürülmesinde, borun (sodyum pentaborat, $\mathrm{Na}_{2} \mathrm{O} .5 \mathrm{~B}_{2} \mathrm{O}_{3} \cdot 10 \mathrm{H}_{2} \mathrm{O}$ ) Tris sulandırıcısına eklenerek ve bileşenleri yerine katılarak hazırlanmış solüsyonlarla, elde edilecek in vitro sonuçların değerlendirilmesi amaçlandı. Çalışma materyali olarak, dölverimi kanıtlanmış ve suni vaginaya sperma vermeye alıştırılmış ergin Ankara tekelerinin normospermik ejakülatları alındı. Çalışmada standart Tris sulandırıcısından glikoz çıkarılıp farklı miktarlarda bor eklenerek hazırlanmış sulandırıcılar (GYB; 1-a, 1-b, 1-c, 1-d), standart Tris sulandırıcısına farklı miktarlarda bor eklenerek hazırlanmış sulandırıcılar (BEK;2-a, 2-b, 2-c, 2-d) ve standart Tris sulandırıcısı (Kontrol) olmak üzere 9 farklı sulandırıcı kullanıldı. Sperma analiz sistemi (CASA) ile total motilite ve progresif motilite değerlerine bakıldığında sırasıyla en yüksek değerinlerin $63,34 \pm 2,32$ ile 1-c ve $\% 38,27 \pm 0,74$ ile 1-d sulandırıcılarına VCL, VSL, VAP, LIN, STR, WOB verilerinin en yüksek 2-d sulandırıcısına ait olduğu belirlendi $(\mathrm{p}<0,001)$. Ölü spermatozoon oranı değerlendirildiğinde en düşük ölü spermatozoon oranının $\% 36,04 \pm 2,58$ ve $\% 36,17 \pm 3,66$ ile sirasıyla 2 -b ve 1 -c sulandırıcılarına ait olduğu gözlemlendi ( $<<0,001)$. Anormal spermatozoon

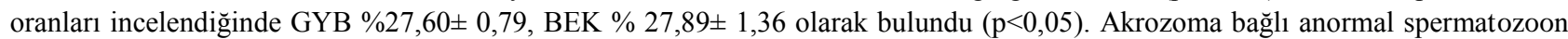
değerleri ise en düşük oran $\% 21,29 \pm 0,97$ ile 2 -c sulandırıcısından elde edildi $(p<0,001)$. Akrozoma bağlı anormal spermatozoon verilerinde ise en düşük oranın ise $\% 6,57 \pm 1,29$ ile 1 -a sulandırıcısına ait olduğu belirlendi $(\mathrm{p}<0,01)$. Sonuç olarak sodyum pentaborat'ın Ankara tekesi çözüm sonu spermatolojik parametrelere olan olumlu bazı etkileri ortaya konulmuştur.

Anahtar sözcükler: Ankara tekesi, bor, sperma, spermatolojik özellikler.

\section{Introduction}

Conservation of genetic resources of Angora bucks, which is a unique Anatolian goat breed of Anatolia, is important for the continuity of the breed. The extenders' composition and amount for the kryopreservation of goat semen could not be optimized with the studies done worldwide (23).

Research should be continued in order to reach the optimal success in semen washing, extending and freezing techniques in goat semen $(17,24)$. Most of the

\footnotetext{
* Bu çalışma 'Ankara tekesi spermasının dondurulmasında Tris sulandırıcı bileşenleri yerine katilan Bor'un (Sodyum pentaborat) çözüm sonu sperma kalitesi üzerine etkisi' adlı tezden üretilmiştir.
} 
previous studies intended to increase fertilisation ability of frozen semen and various chemicals, antioxidants and additives were used in freezing processes $(2,4)$. In the researches done with CASA system, evaluation of postthaw skimmed milk and Tris extenders were used for Norduz (23) and Florida goat semen (7). According to the results obtained Tris was noted to give better results at speed parameters than skimmed milk.

While metabolic activity of spermatozoa gradually decreases with the effect of cold, the production of harmful products also decrease with the metabolism. Another important factor is the activation of glucose-6fosfate-dehydrogenase which is an intracellular enzyme, and while ATP level decreases Adenosinemonophosphate/ Adenosinediphosphate (AMP/ADP) level increases (13, 21).

With researches based on dosage and time, the effects of boron mineral on the reproductive system have mostly been tried to put forth on rats and mice $(8,15$, 16). Ince et al., has observed that diet with high boron concentration decreases lipid peroxidation and improves antioxidant mechanism in a study done with rats (11). On a similar study done on humans various tests were performed in order to determine DNA damage and oxidative stress parameters. As a result of the tests conducted it was determined that even the lowest dosage of boron application supported antioxidant enzyme activity and even with the highest concentration no genotoxic effect was observed on a cellular basis and with increasing doses reduction of oxidative stress was detected (26).

In this reseach boron element was added or used instead of some of the components of Tris extender in freezing Angora goat's semen, which is a breed particular for our country. Post-thaw spermatozoon motility parameters (total motility, progressive motility, VSL, VAP, VCL, STR, LIN, WOB), dead spermatozoon ratio, abnormal spermatozoon ratio and abnormal spermatozoon with relation to acrosome were determined. Thus, increasing the fertilisation ability of frozen semen and usage of boron element in semen freezing were intended.

\section{Materials and Methods}

In this research, ejaculates taken from Angora goats which are over 1 year old and held in special compartments in Ankara University Faculty of Veterinary Medicine Practice and Research Farm were used (Ethic No: 2010-96-341).

In the study, at least 10 goats were tried for semen collection and among the ejaculates collected from these goats the semen with reported normospermi quality for goats (22) were used.

Boron added extenders (BAD) and extenders with boron insted of glucose (GIB) were prepared for the groups other than the control groups (Table 1). Osmotic pressure values were measured with automatic osmometer (Knauer ${ }^{\circledR}$, Germany); $\mathrm{pH}$ values were measured with $\mathrm{pH}$ meter (isolab ${ }^{\circledR}, \mathrm{pH} 111$, Türkiye). All the groups of the extended semen were dosed so that 0.25 $\mathrm{ml}$ would include $200 \times 10^{6}$ spermatozoa. The semen put in sequins were left in $+4^{0} \mathrm{C}$ for 2 hours for equlibration. Later, semen were frozen in liquid nitrogen vapour and stored in a liquid nitrogen tank (in liquid nitrogen $\left.196^{\circ} \mathrm{C}\right)$.

Semen processed as explained before were thawed in $37^{\circ} \mathrm{C}$ water bath for 35 seconds and then; were analysed in Computer Aid Sperm Analyser (CASA) with Sperm Class Analyzer (SCA ${ }^{\circledR}$ v.4.2, Barcelona, Spain) system with regard to spermatozoa motility properties (spermatozoa total motility $\%$ and progressive motility $\%$, VSL, VAP, VCL, STR, LIN, WOB), dead spermatozoa ratio (\%), abnormal spermatozoa ratio (\%), abnormal spermatozoa ratio with relation to acrosome (\%) parameters. When the spermatozoa motility properties were being calculated the speed standards were set as static, slow $>60 \mu \mathrm{m} / \mathrm{s}$, moderate $>90 \mu \mathrm{m} / \mathrm{s}$, fast $>120$ $\mu \mathrm{m} / \mathrm{s} .5 \mu \mathrm{l}$ of each sample was taken and evaluated in 20 $\mu$ object slides with 4 compartments, which are specially produced for CASA system (leja ${ }^{\circledR} 20$ ). In 7 different regions for each sample at least 200 and at most 350 spermatozoa were analysed using a 60 framed camera

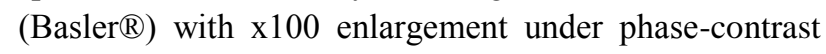
microscobe connected to the system.

Table 1. Extender components.

Tablo 1. Sulandırıcı bileşenleri.

\begin{tabular}{|c|c|c|c|c|c|c|c|}
\hline Groups & Extender & $\begin{array}{c}\text { Ozmotic pressure } \\
(\mathrm{mOsmol})\end{array}$ & $\mathrm{pH}$ & Tris (gr) & Sitric acid (gr) & Glucose (gr) & Sodium Pentaborate (gr) \\
\hline \multirow{4}{*}{ GIB } & $1-\mathrm{a}$ & 305 & 7,28 & 3,63 & 1,82 & - & 0,3 \\
\hline & $1-b$ & 304 & 7,21 & 3,63 & 1,82 & - & 0,5 \\
\hline & $1-\mathrm{c}$ & 331 & 7,08 & 3,63 & 1,82 & - & 0,7 \\
\hline & $1-\mathrm{d}$ & 342 & 7,05 & 3,63 & 1,82 & - & 0,9 \\
\hline \multirow{4}{*}{ BAD } & $2-a$ & 338 & 7,26 & 3,63 & 1,82 & 0,5 & 0,2 \\
\hline & $2-b$ & 335 & 7,21 & 3,63 & 1,82 & 0,5 & 0,4 \\
\hline & $2-c$ & 349 & 7,12 & 3,63 & 1,82 & 0,5 & 0,6 \\
\hline & 2-d & 327 & 7,03 & 3,63 & 1,82 & 0,5 & 0,8 \\
\hline \multicolumn{2}{|c|}{ CONTROL } & 333 & 7,20 & 3,63 & 1,82 & 0,5 & - \\
\hline
\end{tabular}


When determining post-thaw dead-alive ratios dual florescent staining method (Duo Vital ${ }^{\circledR}$, Microptics ${ }^{\circledR}$, Spain) was used and evaluation was done by the florescent microscope which is integrated to CASA system (14).

When evaluating abnormal spermatozoa ratios the semen morphology kit were used in accordance with the reference literature (Sperm Blue ${ }^{\circledR}$, Microptics ${ }^{\circledR}$, Spain) (27).

Statistical analysis; The statistical significance of the difference between the extenders with existing variables were analyzed with one way analyzis of variance (ANOVA). For the differences in variables which were significant Tukey test was used as a further stage (post-hoc) test to determine which extender caused the difference. The descriptive measurements of variables were given in the tables as "Arithmetic

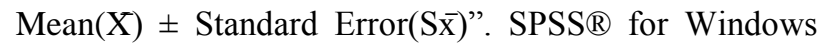
14.1 (Licence No:9869264) package programme was used in analysis of the data.

\section{Results}

When total motility values were compared, it was determined that the highest value belonged to 1-c extender with $63,34 \%$; the lowest value belonged to 2 -d extender with $32,29 \%$; and also it was observed that 1-b, 1-d and 2-b extenders had higher values when compared to control extender (Table 2).

In this respect, it was determined that the highest progressive motility value belonged to $1-d$ extender with $38,27 \%$, the lowest value belonged to control extender with $17,86 \%$ and all the other extenders' progressive motility values were higher than the control extender.

When the kinetic parameters of the semen were examined it was detected that the highest VCL, VSL, VAP, LIN, STR, WOB values respectively; 146,40 $\pm 3,37$, $100,29 \pm 1,50, \quad 117,93 \pm 2,07, \quad 68,60 \pm 0,87, \quad 85,06$, $80,63 \pm 0,72$ belonged to $2-\mathrm{d}$ extender, the lowest VCL, VSL, VAP datas respectively; 91,79 $\pm 3,01,54,04 \pm 1,77$, $68,66 \pm 2,25$ belonged to control extender, LIN values; $57,21 \pm 2,31$ and $57,21 \pm 0,89$ belonged to $2-b$ and 2 -c respectively. The lowest STR belonged to 2-b with $77,23 \pm 0,81$; and the lowest WOB belonged to 2-c with $73,31 \pm 0,87$. Along with this, it was determined that all the extenders other than 2-b and 2-c had higher LIN and WOB values when compared to control extender, and all the extenders other than 2-a, 2-b and 2-c had higher STR values than the control extender. The differences between the semen motility parameters of different extenders were significant $(\mathrm{p}<0,001)$. (Figure 1, Table 2).

When the values of the extenders were compared it was determined that the lowest dead spermatozoa ratio belonged to 2-b and 1-c with $36,04 \pm 2,58 \%$ and $36,17 \pm 3,66 \%$ values respectively and the highest ratio belonged to 2 -d extender with $62,03 \pm 3,61 \%$. The values of 1-b and 1-d extenders were observed lower than control extenders values ( $p<0,001)$ (Figure 2, Table3).

When abnormal spermatozoa ratios were examined it was observed that the highest ratio belonged to 2-d extender with $37,14 \pm 1,20 \%$, and the lowest value was obtained from 2-c extender with $21,29 \pm 0,97 \%$. All the extenders', apart from 2-b extender, abnormal spermatozoa ratios were observed to be lower than the control groups values $(\mathrm{p}<0,001)$.

When the values of abnormal spermatozoa with relation to acrosome were taken into consideration it was observed that the highest ratio belonged to the control group with $15,14 \pm 1,87 \%$, and the lowest ratio belonged to 1 -a with $6,57 \pm 1,29 \%$. For the acrosome values all the extenders ratios were found to be lower than the control group $(\mathrm{p}<0,01)$ (Figure3,Table4)

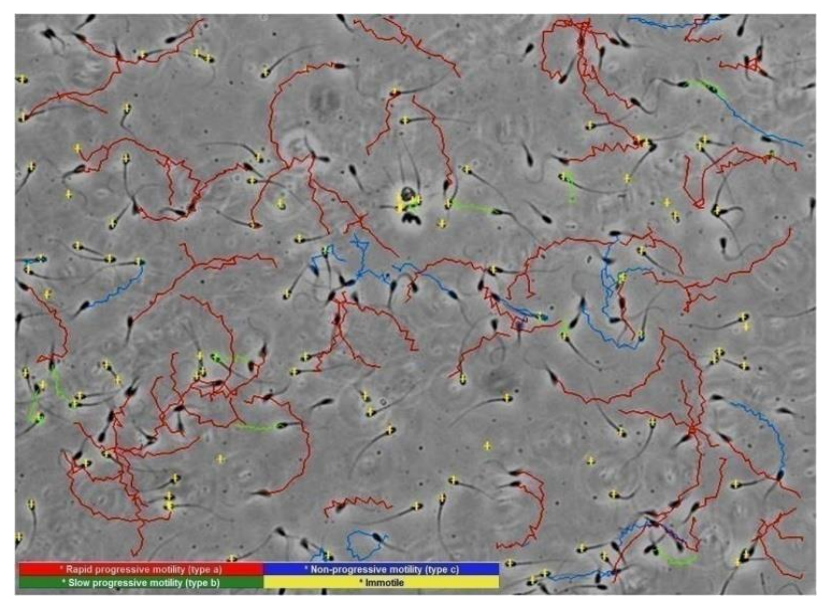

Figure 1. Spermatozoon motility parameters (type a: rapid progressive motility (red), type b: slow progressive motility (green), type c: non-progressive motility (blue), type d: immotile (yellow)).

Şekil 1. Spermatozoon hareket özellikleri (type a: hızl progresif motil (kırmızı), type b: yavaş progresif motil (yeşil), type c: progresif olmayan motil (mavi), type d: motil olmayan (sar1)).

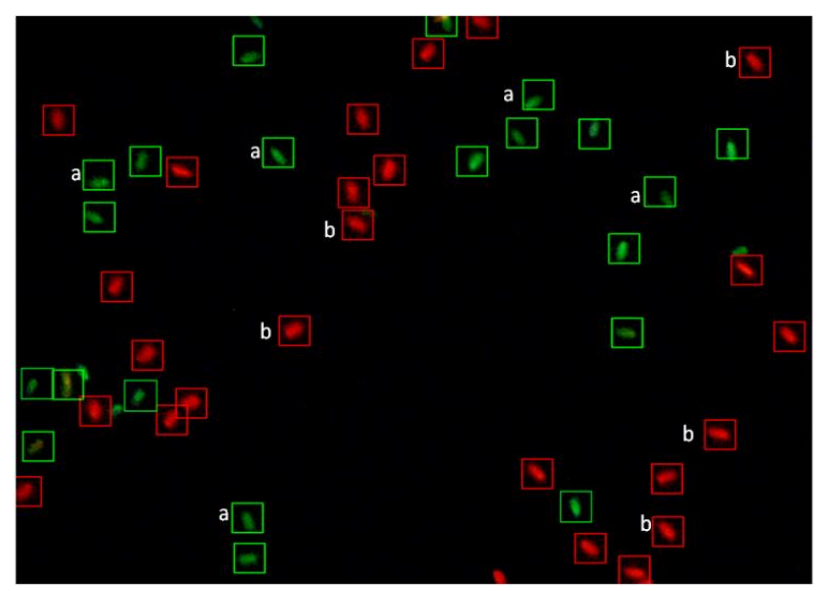

Figure 2. Spermatozoon viability (a: viable spermatozoon, b: dead spermatozoon).

Şekil 2. Ölü ve canlı spermatozoon (a: canlı spermatozoon, b: ölü spermatozoon). 


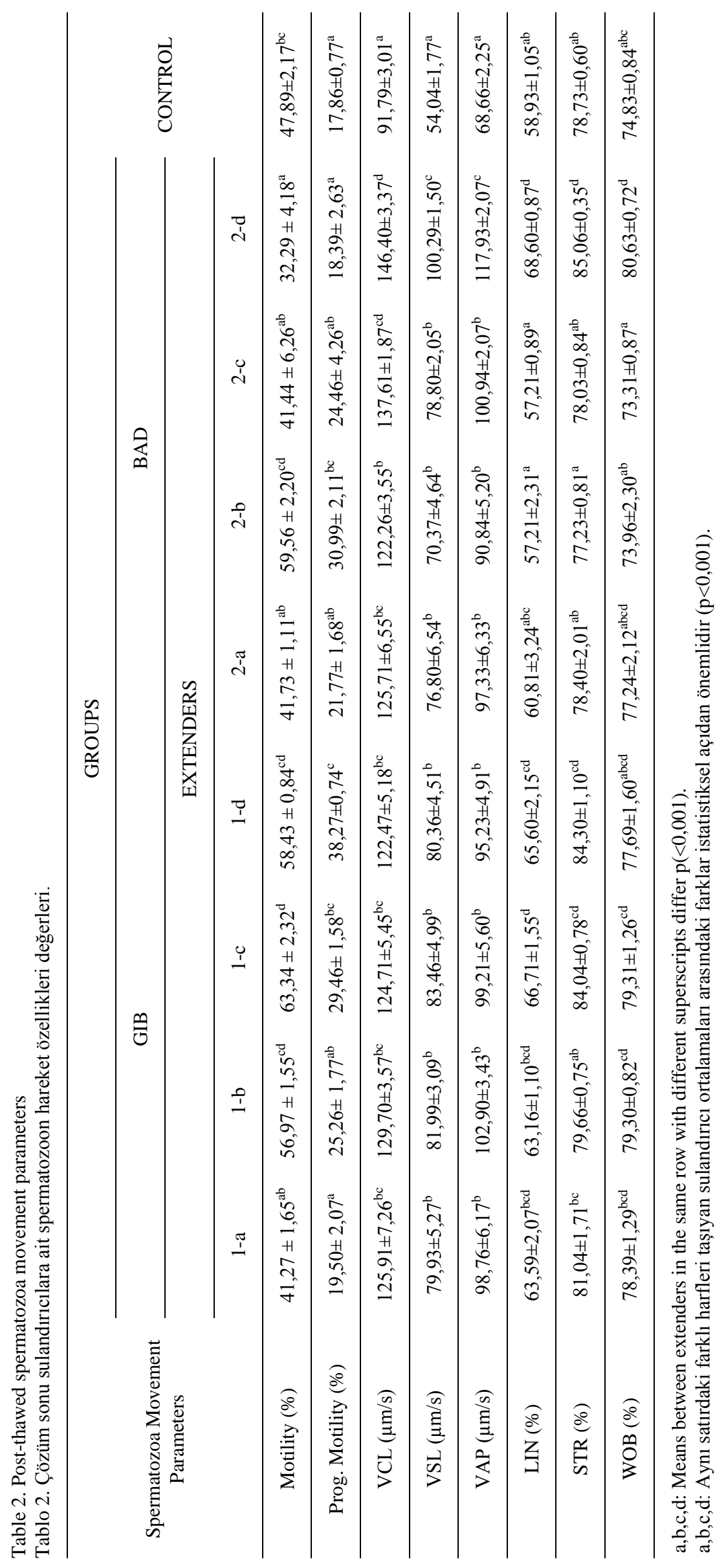




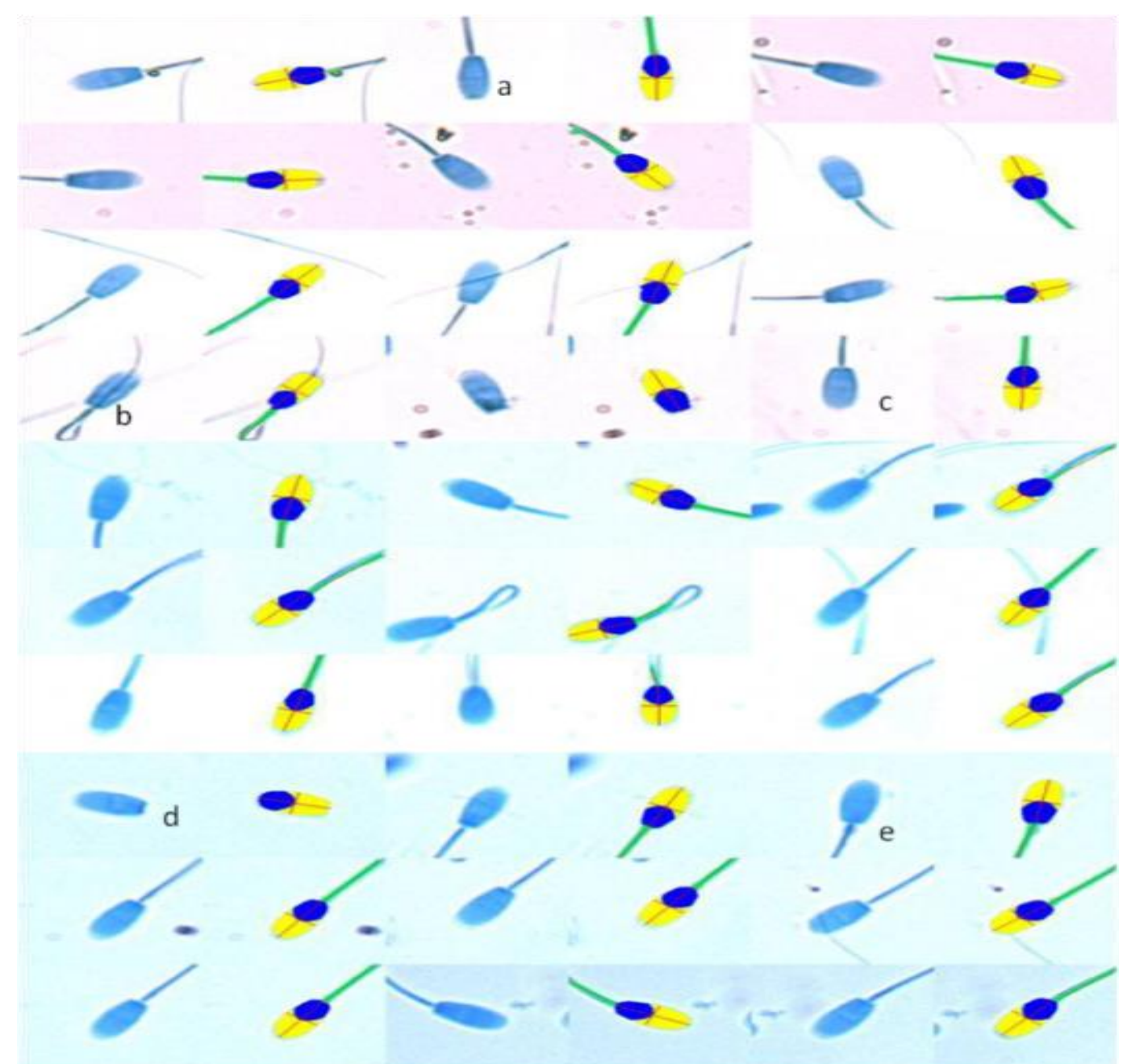

Figure 3. Spermatozoon morphology (a: acrosomal damage, b: rolled tail c: normal spermatozoon, d: head without tail, e: proximal cytoplasmic droplet).

Şekil 3. Anormal spermatozoonlar (a: akrozom hasarı, b: kıvrık kuyruk, c: normal spermatozoon, d: kopuk baş, e: proksimal sitoplazmik damlacık).

Table 3. Post-thaw spermatozoon viability values.

Tablo 3 Çözüm sonu sulandırıcılara ait ölü spermatozoa oranı değerleri.

\begin{tabular}{ccc}
\hline Group & Extender & Dead Spermatozoa $(\%)$ \\
\hline \multirow{4}{*}{ GIB } & $1-\mathrm{a}$ & $51,21 \pm 2,16^{\mathrm{bcd}}$ \\
& $1-\mathrm{b}$ & $40,70 \pm 2,15^{\mathrm{ab}}$ \\
& $1-\mathrm{c}$ & $36,17 \pm 3,66^{\mathrm{a}}$ \\
& $1-\mathrm{d}$ & $40,61 \pm 1,52^{\mathrm{ab}}$ \\
\hline \multirow{3}{*}{ BAD } & $2-\mathrm{a}$ & $52,76 \pm 2,03^{\mathrm{bcd}}$ \\
& $2-\mathrm{b}$ & $36,04 \pm 2,58^{\mathrm{a}}$ \\
& $2-\mathrm{c}$ & $55,23 \pm 4,97^{\mathrm{cd}}$ \\
& $2-\mathrm{d}$ & $62,03 \pm 3,61^{\mathrm{d}}$ \\
\hline
\end{tabular}

a,b,c,d: Mean values of extenders in the same column with different superscripts differ $(\mathrm{p}<0,001)$.

a,b,c,d: Aynı sütunda farklı harfleri taşıyan sulandırıcı ortalamaları arasındaki farklar istatistiksel açıdan önemlidir $(\mathrm{p}<0,001)$.
Table 4. Post-thaw spermatozoon abnormality and acrosomal damage values.

Tablo 4. Çözüm sonu sulandırıcılara ait anormal ve akrozoma bağlı anormal spermatozoa oranı değerleri.

\begin{tabular}{cccc}
\hline Group & Extender & Abnormal $(\%) *$ & Acrosome $(\%) * *$ \\
\hline \multirow{4}{*}{ GIB } & $1-\mathrm{a}$ & $27,14 \pm 1,18^{\mathrm{ab}}$ & $6,57 \pm 1,29^{\mathrm{a}}$ \\
& $1-\mathrm{b}$ & $29,71 \pm 1,21^{\mathrm{bc}}$ & $10,43 \pm 2,22^{\mathrm{ab}}$ \\
& $1-\mathrm{c}$ & $24,86 \pm 1,72^{\mathrm{ab}}$ & $7,43 \pm 1,78^{\mathrm{a}}$ \\
& $1-\mathrm{d}$ & $28,71 \pm 1,81^{\mathrm{bc}}$ & $6,71 \pm 2,00^{\mathrm{a}}$ \\
\hline \multirow{4}{*}{ BAD } & $2-\mathrm{a}$ & $24,57 \pm 0,90^{\mathrm{ab}}$ & $13,29 \pm 1,89^{\mathrm{ab}}$ \\
& $2-\mathrm{b}$ & $21,29 \pm 0,97^{\mathrm{a}}$ & $7,86 \pm 1,94^{\mathrm{ab}}$ \\
& $2-\mathrm{c}$ & $28,57 \pm 2,53^{\mathrm{bc}}$ & $9,29 \pm 1,04^{\mathrm{ab}}$ \\
\hline \multicolumn{2}{c}{ CONTROL } & $37,14 \pm 1,20^{\mathrm{d}}$ & $12,00 \pm 0,44^{\mathrm{ab}}$ \\
\hline
\end{tabular}

$*(\mathrm{p}<0,001), * *(\mathrm{p}<0,01), \mathrm{a}, \mathrm{b}, \mathrm{c}, \mathrm{d}:$ Mean values of extenders in the same column with different superscripts differ.

a,b,c,d: Aynı sütunda farklı harfleri taşıyan sulandırıcı ortalamaları arasındaki farklar önemlidir. 


\section{Discussion and Conclusion}

Preservation of the genetic sources of Angora goats is important for the continuation of the breed. The extenders' composition and amount for the cryopreservation of goat semen could not be optimized with the studies conducted worldwide. In the reseach presented, the effect of semen frozen with boron including extenders on postthaw in vitro spermatological values were studied.

It was detected that semen taken was suitable for freezing and the data obtained from the fresh ejaculates used in the research were in unison with the average values of other researchers who have studied Angora goat semen $(19,22,25)$.

Preservation of goat semen, especially freezing, results in functional, biochemical and structural damage of spermatozoa. As a result of this, losses in liveliness, motility ratios are seen and this losses effect the fertility ratios. For that reason frozen semen's fertility ability is lower than fresh semen's (18).

In the studies conducted different extenders' (Trisbased, milk powder) positive effects on motility have been notified $(1,7,23)$. In the research conducted it was found that the highest value belonged to 1-c extender and the lowest value belonged to 2 -d extender, along with 1b, 1-d and 2-b extenders values were higher than the control extender. In terms of total motility GIB group gave more positive results when compared to control group $(\mathrm{p}<0,001)$. In the recent studies, the relation between spermatozoa total and progressive motility and speed (velocity) values were examined and it was determined that the group with higher speed values in motility gives better fertility results $(10,12)$. When the progressive motility values were examined it was determined that the highest value belonged to $1-\mathrm{d}$, the lowest value belonged to the control extender and all the other extenders had higher progressive motility values when compared to the control extender. Sodium pentaborate may have provided intracellular energy requirements especially in freezing and thawing processes. In the studies mentioned above; the high motility ratios without the usage of glucose, which plays an important role in the foreseen energy mechanisms, give rise to the thought that boron may be used as an energy source for post-thaw process. Along with this it was determined that the boron added to the extender had no negative effect on the post-thaw motility values and also increases progressive motility. With respect to all the extenders spermatozoa motility values being higher than the control group, it can be concluded that this could have possitive effects on fertility.

Post-thaw semen motility parameters' evaluation in the CASA system and these parameters' relation with fertilisation was analysed in several different species. It has been notified by Donnelly et al., (6) and De geyter et al., (5) that semen's several motility parameters are directly proportional in humans; by Farrell et al., (9), Büyükleblebici (3), and Januskauskas et al., (12) in cattle; and by Robayo et al., (20) in goat. When the kinetic parameters were evaluated in the study it was determined that the highest VCL, VSL, VAP, LIN, STR, WOB values belonged to 2-d extender, the lowest VCL, VSL, VAP datas belonged to control extender, the lowest LIN belonged to 2-b and 2-c respectively, the lowest STR belonged to 2-b and the lowest WOB belonged to 2c. Along with this it was detected that all the extenders other than 2-b and 2-c extenders, LIN and WOB values were higher than control extender's values, and all the STR values of extenders other than 2-a, 2-b, 2-c extenders were higher than control group's values $(\mathrm{p}<0,001)$.

It has been notified by Büyükleblebici (3) that the pregnancy ratios of semen with high post-thaw LIN values are higher. Whereas Januskauskas et al., (12) have not been able to form a relation between LIN parameter and fertilisation in their studies. About the subject Donnelly et al., (6) have obtained higher pregnancy ratios from human semen with high VCL, VSL and VAP values. Within these parameters, VAP parameter has shown the most significant relation with pregnancy ratios. It has also been notified that STR and LIN values are paralel to the fertilisation ability. On the other hand, De geyter et al., (5) have noted that higher VSL parameter in human semen increases the fertilisation ability. Similar to this research, Robayo et al., (20) have studied goat semens motility properties and as a result notified that high VCL and VAP valued semen have higher ability to pass through servical mucus and that the results obtained have statistical importance. Parallel to this, it was deducted from the study conducted that fertilization rates may be increased by the high spermatozoa motility parameters. As a result of postthaw spermatozoa motility values of extenders turning out to be higher than the control group, it was considered that different amounts of sodium pentaborate added to the extenders have a positive effect on semen's fertility ability. However, this hypothesis has to be supported by fertility studies.

When an ejaculate is being evaluated motility is the most commonly used parameter and as known this depends on mitochondrial function. ATP, that is formed as a result of oxidative fosforilation in the mitochondria's inner membrane, is passed to the microtubules as an energy source for motility. Mitochondrial damage is considered when motility is decreased $(13,21)$. In the researches conducted on humans (26) and rats (11) it was notified that boron element reduces lipid peroxidation and thus has an antioxidative effect. Similar to these studies, when the data from the extenders are considered it can be detected that the lowest dead spermatozoa ratio belongs to 2-b and 1-c extenders and the highest ratio 
belongs to 2-d extender. The data from 1-b and 1-d extenders were found to be lower than the control group's data. The dead spermatozoa data of different extenders obtained from the research were statistically significant $(p<0,001)$. According to this, it was observed that when the positive effects of boron mineral on antioxidative, $\mathrm{Na} / \mathrm{K}$ pump or energy metabolisms are considered it has a positive effect on spermatozoa viability.

Spermatozoa motility and morphology are the most important spermatological parameters for the detection of fertilisation ability (6). Some researchers have investigated post-thaw abnormal spermatozoa values in goats. Tekin, (23) and Dorada et al., (7) have detected post-thaw abnormal spermatozoa ratios in the study they performed with frozen semen extended with Tris and skimmed milk powder extenders. In this respect, when the data of the extenders were considered it was observed that Tekin's (23) skimmed milk value is only lower than 2-b extender, and Tris value is only higher than 2-d and control values. Similarly, it was found that Dorado et al.'s, (7) skimmed milk data was higher than 1-a, 1-c, 2a, 2-c extenders and Tris data was only lower than 2-d and control extenders. The differences of the abnormal spermatozoa ratios among the extenders were detected to be significant $(p<0,001)$. It was observed among the extenders that abnormal spermatozoa with relation to acrosome had statistically significant differences ( $p<0,01)$. According to these data, it can be deducted that sodium pentaborate added to the extenders does not have a negative effect on spermatozoa's morphological structure and some ratios even reduce abnormal spermatozoa ratios.

In the studies conducted on goats, the post-thaw in vitro values of semen frozen with different extenders were evaluated with CASA system $(1,7,23)$. The differences between the data obtained from the study presented and other researches using the same analysis system (SCA) may be caused by the usage of different breeds of goats. In addition to these it can be considered that sodium pentaborate added to the extenders in different doses may have had a positive effect on postthaw semen kinetic motions.

As a result, it can be pointed out that sodium pentaborate used in the research may be an alternative substance for the extenders to be positively developed and it has no negative effect along with increasing some parameters in a positive way when frozen-thawed semen parameters are considered. However, further studies must be planned and supported with fertility parameter in order to ground this study more profoundly.

\section{Acknowledgment}

Present research was supported by TÜBİTAKTOVAG. Project number: 1100898.

\section{References}

1. Berlinguer F, Madeddu M, Pasciu V, Succu S, Spezzigu A, Satta V, Mereu P, Leoni GG, Naitana S (2009): Semen molecular and cellular features: these parameters can reliably predict subsequent ART outcome in a goat model. Reproductive Biology and Endocrinology, 7, 125.

2. Bucak MN, Uysal O (2008): The role of antioxidants in freezing of Saanen goat semen. Indian Vet J, 85,148-150.

3. Büyükleblebici S (2012): Farklı Sulandirıcılar ile dondurulan boğa spermasinda İ Vitro ve İ Vivo Değerlendirmeler. Doktora Tezi, Ankara Üniversitesi Sağlik Bilimleri Enstitüsü.

4. Daşkın A, Tekin N (1996): The effect of egg-yolk on the quality of frozen Angora buck semen. Tr J of Vet and Ani Sci, 20, 395-398.

5. De Geyter C, De Geyter M, Koppers B, Nieschlag $\mathbf{E}$ (1998): Diagnostic accuracy of computer-assisted sperm motion analysis. Human Reproduction, 13, 2512-2520.

6. Donnelly ET, Lewis SEM, Mcnally JA, Thompson W (1998): In vitro fertilization and pregnancy rates: the influence of sperm motility and morphology on IVF outcome. Fertility and Sterility, 70, 305-314.

7. Dorado J, Molına I, Munoz-Serrano A, Hidalgo M (2010): Identification of sperm subpopulations with defined motility characteristics in ejaculates from Florida goats. Theriogenology, 74, 795-804.

8. Espinoza-Navarro O, Vilaxa A, Granifo L, Rojas S, Rodriguez H (2007): Histological study on the male reproductive organs of mouse CF1 treated with Boron.Int J Morphol, 25, 341-346.

9. Farrel PB, Presicce GA, Brockett CC, Foote RH (1998): Quantification of bull sperm characteristics measured by computer-assisted sperm analysis (CASA) and the relationship to fertility. Theriogenology, 49, 871-879.

10. Garcia-Macias V, De Paz $\mathbf{P}$, Martinez-Pastor F, Alvarez M, Gomes-Alves S, Bernardo J, Anel E, Anel L (2007): DNA fragmentation assessment by flowcytometry and sperm-bos-halamox (bright-field microscopy and floresence microscopy) in bull sperm. Journal of Andrology, 30, 88-98.

11. Ince S, Kucukkurt I, Cigerci IH, Fidan AF, Eryavuz A (2010): The effects of dietary Boric Acid and Borax supplementation on lipid peroxidation, antioxidant activity, and DNA damage in rats. Journal of Trace Elements in Medicine and Biology, 24, 161-164.

12. Januskauskas A, Johannisson A, Rodriguez-Martinez H (2003): Subtle membrane changes in cryopreserved bull semen in relation with sperm viability, chromatin structure and field fertility. Theriogenology, 60, 743-758.

13. Januskauskas A, Zillinskas H (2002):Bull semen evaluation postthaw and relation of semen charecteristics to bull's fertility. Veterinarija ir zootechnika, 17, 1-8.

14. Johnston SD, Lopez-Fernandez C, Gosalbez A, Zee Y, Holt WV, Allen C, Gosalvez J (2007): The relationship between sperm morphology and chromatin integrity in the Koala (phascolarctos cinereus) as assessed by the sperm chromatin dispersion test ( $s c d t$ ). Journal of Andrology, 28, 6.

15. Ku WW, Chapin RE, Moseman RF, Brink RE, Pierce KD, Adams KY (1991): Tissue distribution of boron in male fischer rats. Toxicol Appl Pharmacol, 111, 145-151. 
16. Ku WW, Chapin RE, Wine RN, Gladen BC (1993): Testicular toxicity of boric acid: relationship of dose to lesion development and lack of recovery in the f344 rat. Reprod Toxicol, 7, 305-319.

17. Kulaksız R, Çebi Ç, Akçay E, Daşkın A (2010): The protective effect of egg yolk from different avian species during the cryopreservation of Karayaka ram semen. Small Rum Res, 88, 12-15.

18. Kulaksız R, Daşkın A (2010): In vitro evaluation of saanen buck semen frozen in different extenders supplemented with various antioxidants. Ankara Üniv Vet Fak Derg, 57, 151-156.

19. Ritar AJ, Mendoza G, Salamon, S, White IG (1992): Frequent semen collection and sperm reserves of the male Angora Goat (Capra Hircus). J Reprod Fert, 95, 97-102.

20. Robayo I, Montenegro V, Valdes C, Cox JF (2008): CASA assessment of kinematic parameters of ram spermatozoa and their relationship to migration efficiency in ruminant cervical mucus. Reprod Dom Anim, 43, 393399.

21. Ruiz-Pessini E, Alvarez E, Enriquez J, Lopez-Perez M (2001): Association between seminal plasma carnitine and sperm mitochondrial enzymatic activities. Int J And, 24, 335-340.

22. Sevinç A, Tekin N, Yurdaydın N, Kale N (1985): Çifteler harası tiftik tekelerinin başlıca spermatolojik özellikleri üzerinde araştırmalar. Doğa Bilim Derg, 9, 265-273.
23. Tekin K (2011): İki farklı sulandirıcı ile dondurulan Norduz tekesi spermasinin motilite, vap, vcl, vsl parametreleri üzerinden değerlendirilmesi. Yüksek Lisans Tezi, Ankara Üniveresitesi Sağlık Bilimleri Enstitüsü.

24. Tekin N, Günzel-Apel AR, Yurdaydın N, Yavaş Y, Daşkın A, Keskin O, Etem H (1991): Östrusları sinkronize edilen koyunlarda suni tohumlama yöntemiyle elde edilen dölverimi. Ankara Üniv Vet Fak Derg, 38, 60-73.

25. Tekin N, Yurdaydın N, Daşkın A (1996): Ankara keçilerinden değişik yöntemlerle sperma alınması ve değerlendirilmesi. Ankara Üniv Vet Fak Derg, 43, 397-403.

26. Turkez H, Geyıkoglu F, Tatar A, Keles S, Ozkan A (2007): Effects of some Boron compounds on peripheral human blood. Z Naturforsch, 62, 889-896.

27. Van der Horst G, Maree L (2009): SpermBlue: a new universal stain for human and animal sperm which is also amenable to automated sperm morphology analysis. Biotech Histochem, 84, 299-308.

Geliş tarihi: 03.07.2014 / Kabul tarihi: 10.02.2015

Address for Correspondence:

Dr. Mehmet Borga Tirpan,

Ankara University,

Faculty of Veterinary Medicine,

Department of Reproduction and Artificial Insemination, 06110 Dışkapı/Ankara, Turkey.

e-mail:borgat@gmail.com 